\title{
Need Assessment for Material Development in Writing Skill Non-Literature Text Teaching for Indonesian Students of Junior High school in Yogyakarta
}

\author{
Uswatun Hasanah* \\ Indonesian Language and Literature Education \\ of Graduate School \\ Universitas Negeri Yogyakarta \\ Yogyakarta, Indonesia \\ uswatun24pasca.2018@student.uny.ac.id
}

\author{
Kastam Syamsi \\ Indonesian Language and Literature Education \\ of Graduate School \\ Universitas Negeri Yogyakarta \\ Yogyakarta, Indonesia \\ kastam@uny.ac.id
}

\begin{abstract}
Teaching material is one of the supporting fluency of learning in class. Writing skills are skills that are more difficult than other language skills, such as listening, speaking and reading. The teaching material currently has weaknesses in illustrations and more questions so the explanation of the material is incomplete. The purpose of this research is to find out teaching materials that need to be developed in non-literary text writing skills in Indonesian language lessons for junior high school students in Yogyakarta. This research is a qualitative descriptive study. The subjects of this study were 10 Indonesian language teachers in 10 junior high schools in Yogyakarta. Data collection techniques are initial observations in the form of questionnaires and interviews. Data were analyzed by collecting, presenting, and concluding. Validity uses data triangulation techniques. The results showed that the language used in teaching materials in schools was quite good, in terms of content, language, presentation, and graphics, as well as communicative. There are many exercises in the questions, but the shortcomings are in the illustrations and explanations of material that are less detailed. The results of the questionnaire analysis of the need to develop teaching materials for nonliterary text writing skills show that Indonesian language teachers need teaching materials for Indonesian non-literary text writing skills that explain more detailed material and are equipped with illustrations that enhance student enthusiasm for learning in class. Based on the research data above, it can be concluded that it is necessary to develop teaching materials specifically the skill of writing Indonesian non-text texts in the form of textbooks with certain approaches to facilitate student learning in class. The findings indicate that the need for nonliterary textbooks to improve learning.
\end{abstract}

Keyword: $\quad$ teaching materials, writing skill

\section{INTRODUCTION}

The teaching and learning process involves three important components that need to be considered namely the teacher, students, and teaching materials. The types of printed teaching materials that we are familiar with include handouts, books, modules, posters, brochures, and leaflets (Depdiknas, 2008). Textbooks are written learning materials that contain the knowledge of the results of the analysis of the applicable curriculum (Prastowo, 2011). Writing is one of the Indonesian language lessons contained in standart competence and basic competence both at elementary, junior high, and high school levels. Writing is one of the skills used to communicate indirectly.

In the 2013 text-based curriculum, writing activities are contained in literary texts as well as non-literary texts, which often become obstacles for students. Writing on literary texts requires students' imagination and creativity while writing on non-literary texts requires an analysis of a particular problem. In the Indonesian textbooks, junior high school level in the 2013 curriculum contained observational report texts, descriptive response texts, exposition texts, explanatory texts, explanatory texts, biographical texts, procedure text, discussion text, review text, excerpt text, critical response text, challenge text, experiment record text. (Kemendikbud, 2017).

The purpose of this study is as a needs analysis in developing teaching materials to write non-literary texts using a process approach for junior high school students. The results of this study are expected to provide information on teaching materials such as what needs to be developed to facilitate student learning about writing non-literary texts for junior high school students.

\section{a) Teaching Material}

\section{LITERATURE REVIEW}

Teaching material is a set of learning materials that arranged coherently and systematically so that students can master competencies in an integrated and integrated manner (Depdiknas, 2008). Teaching materials that are systematically designed help student learning systems that are following the applicable curriculum. Teaching materials compiled by the teacher are not only in the form of textbooks, but can be sourced from any reference. Teaching material does not only contain knowledge material, but also instructions for learning both teacher and student, competencies to be achieved, supporting information, exercises, worksheets, and evaluation (Lestari, 2013). A 
teaching material that is designed and written initially and the system can be used to support the learning process and can influence success in the teaching and learning process (Ardiansyah, Corebima, and Rohman, 2016). Lessons and teaching materials or textbooks are two complementary things. Learning will be more effective if it is equipped with learning resources in the form of textbooks. Textbooks can be arranged and used well. Components such as problems of students, teachers, learning materials, and exercises must be integrated into the textbook (Mustafa, 2016).

There are several functions of teaching materials including First, guidelines for teachers in the learning process, as well as the substance that must be taught to students. Second, guidelines for students in the learning process. Third, as an evaluation tool mastery of learning outcomes (Belawati, 2003). Besides, teaching materials are prepared with the aim of preparing materials that are adapted to the applicable curriculum and taking into account the needs of students that are following the characteristics and environment of students. As well as helping students obtain teaching materials that can support the learning process and facilitate the teacher in the learning process (Belawati, 2003).

Textbooks are written learning materials that contain the knowledge of the results of the analysis of the applicable curriculum (Prastowo, 2011). There are several advantages of learning using textbooks, according to Mulyasa (2006), are: First, focusing on the individual abilities of students, because students can work alone and be responsible for their actions. Second, there is control over student learning outcomes regarding competency standards that students must achieve. Third, the curriculum is relevant, namely the existence of objectives and ways of delivery. So students know the ultimate goal of learning.

Eligibility in textbooks according to the (Depdiknas, 2008) there are four components, namely: the feasibility of content, linguistic, presentation, and graphic. Components of content eligibility include conformity with Competency Standards and Basic Competencies, child development, the need for teaching materials, the truth of the substance of learning materials, benefits, and compliance with moral and social values. While the linguistic component contains readability, clarity of information, conformity with Indonesian language rules, and the use of language effectively and efficiently. The presentation component relates to the clarity of the indicators to be achieved, the order in which they are presented, providing motivation and completeness of the information. Finally, the graphic component contains the use of fonts, types, sizes, layouts, illustrations, drawings, and taper designs. The four elements of eligibility in the textbook are not much different from the opinion of Muslich (2010).

The following is the standard of content suitability according to Muslich (2010), firstly, there is material compatibility with Competency Standards and Basic
Competencies including material completeness, material breadth, and material depth. Second, the accuracy of the material, which includes: accuracy of concepts and definitions, the accuracy of principles, the accuracy of procedures, accuracy of examples, facts, and illustrations, as well as accuracy of questions. Third, learning support material is directed at: its suitability with the development of science and technology, recency of features, examples, and references, reasoning, problem-solving, the interconnection between concepts, communication, application, material attractiveness, encouraging the search for further information, and enrichment material.

As for the graphic standards, there are also three, namely, first, the size of the book, which includes the suitability of the book size with ISO standards and the size of the book content. Second, the design of the book skin, which includes: layout (starting from appearance, composition and size, as well as colour), the typography of the book skin, and the use of letters. Third, letter design, which includes a reflection of book content, layout harmony, layout completeness, layout comprehension, the typography of book content, and an illustration of content (Muslich, 2010).

b) Development

Development is a systematic application of a knowledge that is directed at the production of useful materials in devices, methods, including design to meet certain requirements (Putra, 2012). Several factors can affect the learning system, namely teacher factors, student factors, facilities and infrastructure factors, and environmental factors. Each of these factors will influence the learning process, for example, the teacher factor, teachers who are competent in their field will be able to motivate and set an example for students. Besides, students can easily discuss the material delivered by the teacher and achieve the learning objectives (Sanjaya, 2006).

\section{b) Writing}

Writing is a skill that is not possessed from birth but is obtained if accustomed to doing it (Langan, 2011). Writing is an activity carried out to express ideas in writing, besides writing also includes the types of skills acquired through learning and practising. Writing skills can be possessed by someone after going through a process so that a writer has a basic knowledge about writing and can benefit from these activities (Wiyanto, 2004). Writing goals for students include assessment, critical thinking, understanding, broadening learning, improving communication skills, and to train students in certain disciplines (Coffin, Curry, Goodman, Hewings, Lilis, and Swann, 2003).

There are two writing skills learned in Indonesian language namely literary texts and non-literary texts. Nonliterary texts studied for junior high school students in accordance with the 2013 curriculum include observational report text, response text, exposition text, explanatory text, 
biography text, procedure text, discussion text, review text, critical response text, challenge text, recorded text experiment (Wahyudi, 2016).

\section{c) Relevant Study}

Several studies are relevant to the current research, namely Need Analysis on Developing EFL Paragraph Writing Materials at Kalimantan L2 Learners, written by Sabarun and published in the English Language Teaching journal in 2019. In this study try to explore the needs of the target and learning needs. This research was conducted on students of the second semester of the English language semester from the State Islamic Institute of Palangka Raya in the academic year of 2017/198 and the respondents were 20 students writing EFL paragraphs. In this study trying to investigate the target needs and learning needs of students in the classroom in writing lessons.

Besides, there is also a study entitled The Development and Implementation of Learning Materials on Exposition Text to Improve Student Achievement on Indonesian, written by Wenny Silaban, Binary Ambarita, and Usman Hadi in the journal International Education Studies in 2018. In that research aims to develop learning materials on exposition text with a process that will be used as a learning medium in teaching writing in Indonesian. The research is relevant to research that discusses the analysis of the need for teaching materials to be used in learning to write non-literary texts.

\section{METHODOLOGY}

This research is a qualitative descriptive study. In qualitative research, several steps must be done according to Creswell (2008), namely: identifying topics, reviewing the literature, selecting objects, collecting data, analyzing and interpreting data, and reporting and evaluating research. The reason this method is used is related to the object to be studied, namely the textbooks used by teachers in Indonesian language lessons in junior high school.

Data collection techniques in this study were questionnaire and interview. The subjects consisted of 10 Indonesian language teachers from 10 different junior high schools in Yogyakarta. Data validity uses data triangulation techniques. The selection of the right instrument will produce accurate data (Tanzeh, 2009). Data collected in this study used instruments/questionnaires and interviews with junior high school teachers in Yogyakarta. The questionnaire given was related to the accuracy of the aspects of content eligibility, presentation eligibility, language feasibility, and graphic suitability which consisted of 20 questions. The answer choices for the questionnaire are in the form of a scale of 1-5 (gradation $1=$ very less, score $2=$ less, score $3=$ enough, score $4=$ good, score $5=$ very good).

The following questions are asked to teachers relating to the appropriateness of content: 1) conformity with standard competence and basic competence writing non-literacy texts, 2) conformity with students' needs in writing non-literary texts, 3) conformity to the needs of teaching non-literary text materials, 4) truth of material substance writing non-literary texts, 5) Benefits for adding insight into knowledge about writing non-literary texts, 6) Conformity with values, morality, and social, 7) Improving students' non-literary text writing skills. While the questions for language are related to 1) Readability, 2) Clarity of information relating to writing non-literary texts, 3) Compliance with Indonesian language rules. Questions in terms of presentation relate to 1) Clarity of objectives, 2) Order of presentation in writing non-literary texts, 3) Motivation, 4) Interactivity (stimulus and response) in writing non-literary texts, 5) Completeness of information about writing non-literary texts, 6) Examples writing diverse non-literary texts. And questions related to graphics include 1) The use of fonts (types and sizes), 2) Layout, layout, 3) Illustration, graphics, pictures, photos, 4) Display design attracts students' attention.

While interview guidelines are used to interview teachers when conducting needs analysis. Based on the type of data, the data analysis technique used in this study is qualitative data analysis. The value obtained is then interpreted in accordance with predetermined eligibility guidelines.

a) Result

\section{RESULT AND DISCUSSION}

Questionnaire sheet analysis needs the development of teaching materials non-literary text writing skills containing 20 questions related to the content, language, presentation, and graphics in the textbooks used in the learning process in class. While the interviews were conducted to better find out how the teacher's expectations of the textbooks used in class.

TABLE 1. RESULTS OF RESPONSES JUNIOR HIGH SCHOOL TEACHERS IN YOGYKARTA IN TEXTBOOKS USED IN NON-LITERARY TEXT WRITING SKILLS

\begin{tabular}{|c|c|c|c|c|}
\hline Participant & Content & Linguistic & Serving & Finesse \\
\hline $\boldsymbol{A}$ & 3 & 2 & 3 & 3 \\
\hline $\boldsymbol{B}$ & 4 & 4 & 5 & 5 \\
\hline $\boldsymbol{C}$ & 4 & 3 & 3 & 3 \\
\hline $\boldsymbol{D}$ & 4 & 4 & 4 & 4 \\
\hline $\boldsymbol{E}$ & 4 & 4 & 3 & 3 \\
\hline $\boldsymbol{F}$ & 4 & 5 & 4 & 4 \\
\hline $\boldsymbol{G}$ & 3 & 4 & 3 & 2 \\
\hline $\boldsymbol{H}$ & 3 & 3 & 3 & 3 \\
\hline $\boldsymbol{I}$ & 3 & 4 & 3 & 3 \\
\hline $\boldsymbol{J}$ & 3 & 3 & 3 & 2 \\
\hline
\end{tabular}

Note $\quad \begin{aligned} & 1=\text { very less } \\ & 2=\text { less } \\ & 3=\text { enough } \\ & 4=\text { good } \\ & 5=\text { very good }\end{aligned}$


While the results of interviews with teachers obtained several things including textbooks that are still less attractive to students in learning, even though the language used is communicative and the writing is read. However, the lack of illustrations in the book and the lack of a detailed explanation of the material are also one of the factors that reduce student motivation in the learning process and slightly complicate student understanding.

\section{b) Discussion}

The results of the questionnaire analysis distributed to Indonesian language teachers in Yogyakarta all use textbooks as one of the teaching materials in the classroom. Textbooks become one of the teaching materials that are easily obtained by all students, besides that textbooks also develop by the applicable curriculum. Like the current curriculum used is the 2013 curriculum. A good textbook is a book written in good language and easily understood by students, presented interestingly and equipped with pictures and explanations. The content of the textbook also must describe something that by the idea of the writing. Textbooks that contain knowledge can be used as teaching material by teachers and students in the classroom (Depdiknas, 2008).

Based on data from the research that has been done, it is necessary to develop teaching materials in the form of textbooks. Textbooks developed can adjust to the skills to be taught. In textbooks, there are four main points to write non-literary text skills, namely: content, language, presentation, and graphics. Textbooks used in junior high schools in Yogyakarta in the appropriateness of the contents in the category of "enough" with an average score of 3.4, which is by the applicable IC and BC, according to student needs, by the substance of non-literary text writing material, and suitability with moral and social values.

This shows that in terms of the material it is quite good in terms of concept accuracy, definition, principle accuracy, and sample accuracy. Non-literary text writing skills material in textbooks used in schools still needs to be improved one of them with a particular approach, to facilitate students in the writing process. Because the purpose of the preparation of textbooks is to prepare materials that are adapted to the applicable curriculum and consider the needs of students that are by the characteristics and environment of students. As well as helping students and teachers in the learning process.

From the language side of the textbooks used are included in the category of "good" with an average score of 3.7 , which relates to readability, clarity of information relating to writing non-literary texts, as well as compliance with Indonesian language rules. While in terms of presentation in textbooks that are also included in the category of "enough" with an average score of 3.5, performance is related to the clarity of learning objectives, the order in which non-literary text is presented, motivating students, interactivity in writing, completeness of information and examples about writing non-literary texts. In the textbooks used in schools already include clarity of indicators to be achieved, the order of presentation, but lacking in the part of providing motivation and completeness of information, so that students' interest in learning to write is reduced.

Not much different from the graphics included in the category of "enough" with an average score of 3.2, which is related to the use of fonts, layouts, illustrations, graphics, images, photos, and display designs that attract the attention of the rest.

In textbooks used in schools starting from the size of the book, which includes the suitability of the size of the book with ISO standards and the suitability of the size of the contents of the book. Book skin design, which includes: layout (starting from appearance, composition and size, as well as colour), book skin typography, and the use of letters. And the design of letters, which includes a reflection of the contents of the book, the harmony of the layout, completeness of the layout, comprehension of layout, and typography of the contents of the book is good enough. But in the illustration section, the content is very lacking, even though it is one of the factors to attract students' attention to like learning to write.

Based on interview data that has been conducted there are some criticisms and suggestions from junior high school teachers in Yogyakarta, namely relating to the contents and illustrations. Some teachers feel that some parts of the textbooks are used, such as explanations on some less material, less focused discussion, lack of evaluation, and very poor illustrations so that they do not attract students' interest in the learning process. Although the language used is good enough communicative. The teacher hopes that the textbooks that are developed later will make it easier for students to understand the material and increase student motivation in learning, and are packaged with more diverse illustrations to attract students' attention.

Success in the teaching and learning process is not only influenced by the teacher and students but the material taught with approaches, methods and strategies also participates in improving the achievement of learning objectives. Textbooks that focus more on one language skill, namely writing non-literary texts using a certain approach, are likely to be able to improve students' ability to write non-literary texts.

Writing, in general, is a difficult subject for students. Because students must express ideas by the material being taught. By using a particular approach students will more easily pour their creativity because in it there is clear material and is accompanied by steps in the process of writing non-literary texts. In addition to content that makes it easy for students to draw in textbooks, it is also one of the factors to attract/motivate students in learning. 


\section{CONCLUSION}

Based on the results of research that has been done, it can be concluded that teaching materials that need to be developed in non-literary text writing skills for junior high school students are teaching materials in the form of textbooks that focus more on writing skills with a particular approach to improve students' understanding of the material being taught. The feasibility of textbooks used in the field is included in the good category, starting from the feasibility of "enough" content, the feasibility of "good" linguistic, "enough" content, and the feasibility of "sufficient" graphics. However, for some literacy teachers was felt to be lacking in textbooks, so that students' interest was reduced. While good textbooks are packaged intact and systematically and can attract students' interest in the learning process of writing. This study is part of the study of developing textbooks on non-literary text writing skills using a process approach for junior high school students.

\section{REFERENCES}

Ardiansyah, Reza, A.D. Corebima, dan Fatchur Rohman. (2016). Analisis Kebutuhan Pengembangan Bahan Ajar Perubahan Materi Genetik pada Matakuliah Genetika di Universitas Negeri Malang. Seminar Nasional Pendidikan dan Saintek. ISSN: 2557-533X. Hal: 749.

Belawati, Tian. (2003). Materi Pokok Pengembangan Buku Ajar. Jakarta: Universitas Terbuka.

Coffin, Caroline, Mary Jane Curry, Sharon Goodman, Ann Hewings, Theresa M. Lilis, dan Joan Swann. (2003). Teaching Academic Writing. London: Routledge

Creswell, John W. (2008). Research Design, Pendekatan Kualitatif, Kuantitatif, dan Mixed. Bandung: Pustaa Pelajar.
Depdiknas. (2008). Pengembangan Bahan Ajar. Jakarta: Direktorat Jenderal Managemen Pendidikan Dasar dan Menengah, Direktorat Pendidikan Sekolah Menengah Atas.

Kemendikbud. (2017). Panduan Penilaian oleh Pendidik dan Satuan Pendidikan untuk Sekolah Menengah Atas. Jakarta: Direktorat Jenderal Pendidikan Dasar dan Menegah.

Langan, John. (2011). College Writing Skills with Reading. Eight Edition. New York: McGraw-Hill.

Lestari, Ika. (2013). Pengembangan Bahan Ajar Berbasis Kompetensi (Sesuai dengan Kurikulum Tingkat Satuan Pendidikan). Padang: Akademia Permata.

Mulyasa, E. (2006). Kurikulum Berbasis Kompetensi. Bandung: PT Remaja Rosdakarya.

Muslich, Mansur. (2010). Text Book Writing: Dasar-Dasar pemahaman, Penulisan, dan Pemakaian Buku Teks. Jogjakarta: Ar-Ruzz Media.

Prastowo, Andi. (2011). Panduan Kreatif Membuat Bahan Ajar Inovatif: Menciptakan Metode Pembelajaran yang Menarik dan Menyenangkan. Yogyakarta: DIVA Press.

Sabarum. (2019). Need Analysisi on Developing EFL Paragraph Writing Material at Kalimantan L2 Learners. English Language Teaching. 12 (1):186. ISSN: 1916-4741, E-ISSN: 1916-4750.

Sanjaya, Wina. (2006). Strategi Pembelajaran Berorientasi Standar Proses Pendidikan. Jakarta: Kencana.

Silaban, Wenny, Biner Ambarita, dan Usman Hadi. (2018). The Development and Implementation of Learning Material on Expositin Text to Improve Students Achievement on Bahasa Indonesia. International Education Studies. 11 (11): 53. ISSN: 1913-9020, E-ISSN: 1913-9039.

Tanzeh, Ahmad. (2009). Pengantar Metode Penelitian. Yogyakarta: Teras.

Wahyudi, Phaphy. (30 maret 2016). Jenis-Jenis Teks dalam Kurikulum 2013. https://www.slideshare.net/imamwahyudi5682/jenisjenisteks-dalam-kurukulum-2013. Diakses 22 Agustus 2019, Pukul 10:10 WIB.

Wiyanto. Asul. (2004). Terampil Menulis Paragraf. Jakarta: Gramedia Widiasarana Indonesia. 